\title{
The genotoxicity of enantiomeric aliphatic epoxides
}

\author{
J.E. Sinsheimer, R. Chen, S.K. Das, B.H. Hooberman, S. Osorio and Z. You \\ College of Pharmacy, University of Michigan, Ann Arbor, MI 48109-1065, USA
}

(Received 4 June 1992)

(Revision received 3 August 1992)

(Accepted 7 August 1992)

\begin{abstract}
Keywords: Enantiomers of aliphatic epoxides; Salmonella mutagenicity; Chromosomal aberrations; Sister-chromatid exchange
\end{abstract}
\section{Summary}

The (R)- and (S)-optical isomers of 9 epoxides, benzyloxymethyloxirane, epichlorohydrin, glycidol, glycidyl 3-nitrobenzenesulfonate, glycidyl 4-nitrobenzoate, glycidyl tosylate, styrene oxide, glycidyl 1naphthyl ether and glycidyl 4-nitrophenyl ether, have been compared for their in vivo and in vitro genotoxicity. The in vitro short-term test employed was the Ames mutagenicity assay with Salmonella strain TA100. The in vivo tests were chromosomal aberrations (CA) as well as sister-chromatid exchange (SCE) in bone-marrow cells of mice following intraperitoneal administration of these epoxides. Differences in mutagenicity between isomers were established with TA100 for all the compounds. While 13 of the isomers were genotoxic compared to a negative control by CA measurements, only in the case of glycidyl 4-nitrobenzoate could a significant difference be found between isomers by this test. However, with SCE evaluations, differences were detected between the (R)- and (S)-isomers for all the pairs of compounds with the exception of those for benzyloxymethyloxirane and glycidyl 4-nitrophenyl ether. At least in part, differences in the patterns of genotoxicity among compounds can be related to their differences in reaction pathways.

The reactivity of epoxides with nucleophiles that forms the basis of their utility as chemical intermediates could also lead to toxicity subsequent to their reaction with bionucleophiles. The recent increased availability of enantiomeric epoxides has promoted their use for the introduction of stereocenters in complex molecules. The commercial availability of (R)- and (S)-glycidol

Correspondence: Dr. J.E. Sinsheimer, College of Pharmacy, University of Michigan, Ann Arbor, MI 48109-1065, USA. and their derivatives have made them especially useful for this purpose. The synthesis and reactivities of these nonracemic epoxides have recently been reviewed by Hanson (1991).

The structures of the optical isomers under study in the present investigation for their genotoxicity are shown in Table 1 . The designation of $\mathrm{R}$ and $\mathrm{S}$ to glycidol and its derivatives follows the nomenclature rules described by Prelog and Helmchen (1982). The application of these rules will, as shown in Table 1 , result in opposite $(\mathrm{R} / \mathrm{S})$ nomenclature for the same epoxide moiety with different substituent groups. 
TABLE 1

STRUCTURES OF THE TEST COMPOUNDS

\begin{tabular}{|c|c|c|}
\hline Substituents & \multicolumn{2}{|l|}{ Isomers } \\
\hline 1. & $\begin{array}{l}(R)-(-) \\
{[14618-80-5]^{a}}\end{array}$ & $\begin{array}{l}(\mathrm{S})-(+) \\
{[16495-13-9]}\end{array}$ \\
\hline 2. $\mathrm{ClCH}_{2}$ & $\begin{array}{l}(\mathrm{S})-(+) \\
{[67843-74-7]}\end{array}$ & $\begin{array}{l}(\mathrm{R})-(-) \\
{[51594-55-9]}\end{array}$ \\
\hline 3. $\mathrm{HOCH}_{2}$ & $\begin{array}{l}(\mathrm{R})-(+) \\
{[57044-25-4]}\end{array}$ & $\begin{array}{l}(S)-(-) \\
{[60456-23-7]}\end{array}$ \\
\hline 4. & $\begin{array}{l}(S)-(+) \\
{[61249-00-1]}\end{array}$ & $\begin{array}{l}\text { (R) }-(-) \\
{[56715-28-7]}\end{array}$ \\
\hline 5. & $\begin{array}{l}(S)-(+) \\
{[115314-14-2]}\end{array}$ & $\begin{array}{l}(\mathrm{R})-(-) \\
{[115314-17-5]}\end{array}$ \\
\hline $\mathrm{O}_{2} \mathrm{~N}$ & $\begin{array}{l}(\mathrm{S})-(+) \\
{[115459-65-9]}\end{array}$ & $\begin{array}{l}\text { (R)-(-) } \\
{[106268-95-5]}\end{array}$ \\
\hline 7. & $\begin{array}{l}(\mathrm{S})-(+) \\
{[125279-82-5]}\end{array}$ & $\begin{array}{l}(\mathrm{R})-(-) \\
{[125279-81-4]}\end{array}$ \\
\hline 8. & $\begin{array}{l}(S)-(+) \\
{[70987-78-9]}\end{array}$ & $\begin{array}{l}(\mathrm{R})-(-) \\
{[113826-06-5]}\end{array}$ \\
\hline 9. & $\begin{array}{l}(\mathrm{R})-(+) \\
{[20780-53-4]}\end{array}$ & $\begin{array}{l}(\mathrm{S})-(-) \\
{[20780-54-5]}\end{array}$ \\
\hline
\end{tabular}

a Chemical Abstracts Service registry numbers. 
TABLE 2

MUTAGENICITY OF EPOXIDE R AND S ISOMERS IN Salmonella typhimurium TA100

\begin{tabular}{|c|c|c|c|c|}
\hline \multirow{2}{*}{$\begin{array}{l}\text { Compounds } \\
\text { Dose } \\
(\mu \mathrm{mol})\end{array}$} & \multicolumn{2}{|l|}{$\mathbf{R}$} & \multicolumn{2}{|l|}{$S$} \\
\hline & $\begin{array}{l}\text { Revertants } \\
(\text { mean } \pm \text { S.D. })\end{array}$ & $\mathrm{Rev} / \mu \mathrm{mol}^{\mathrm{a}}$ & $\begin{array}{l}\text { Revertants } \\
(\text { mean } \pm \text { S.D. })\end{array}$ & $\mathrm{Rev} / \mu \mathrm{mol}^{\mathrm{a}}$ \\
\hline \multicolumn{5}{|c|}{ Benzyloxymethyloxirane } \\
\hline 0 & $111 \pm 16$ & $260 \pm 6$ & $111 \pm 16$ & $288 \pm 6$ \\
\hline 0.05 & $116 \pm 11$ & & $107 \pm 7$ & \\
\hline 0.1 & $123 \pm 13$ & & $124 \pm 10$ & \\
\hline 0.33 & $184 \pm 24$ & & $196 \pm 11$ & \\
\hline 0.66 & $265 \pm 51$ & & $289 \pm 35$ & \\
\hline 1 & $336 \pm 20$ & & $344 \pm 19$ & \\
\hline 3 & $894 \pm 43$ & & $982 \pm 23$ & \\
\hline \multicolumn{5}{|c|}{ Epichlorohydrin } \\
\hline 0 & $90 \pm 14$ & $208 \pm 3$ & $90 \pm 14$ & $161 \pm$ \\
\hline 0.05 & $96 \pm 6$ & & $113 \pm 9$ & \\
\hline 0.1 & $110 \pm 15$ & & $107 \pm 6$ & \\
\hline 0.2 & $119 \pm 12$ & & $118 \pm 14$ & \\
\hline 0.4 & $170 \pm 10$ & & $164 \pm 10$ & \\
\hline 0.8 & $248 \pm 22$ & & $232 \pm 20$ & \\
\hline 1.6 & $407 \pm 31$ & & $356 \pm 24$ & \\
\hline 3.2 & $760 \pm 38$ & & $601 \pm 13$ & \\
\hline \multicolumn{5}{|l|}{ Glycidol } \\
\hline 0 & $145 \pm 25$ & $598 \pm 13$ & $145 \pm 25$ & $355 \pm 14$ \\
\hline 0.05 & $195 \pm 31$ & & $156 \pm 25$ & \\
\hline 0.1 & $245 \pm 13$ & & $185 \pm 29$ & \\
\hline 0.2 & $306 \pm 27$ & & $229 \pm 18$ & \\
\hline 0.4 & $455 \pm 28$ & & $308 \pm 20$ & \\
\hline 0.8 & $632 \pm 86$ & & $426 \pm 59$ & \\
\hline 1.6 & $1131 \pm 46$ & & $717 \pm 105$ & \\
\hline \multicolumn{5}{|c|}{ Glycidyl 1-naphthyl ether } \\
\hline 0 & $126 \pm 16$ & $9268 \pm 310$ & $126 \pm 16$ & $8135 \pm 229$ \\
\hline 0.01 & $318 \pm 50$ & & $244 \pm 22$ & \\
\hline 0.025 & $576 \pm 72$ & & $386 \pm 44$ & \\
\hline 0.05 & $899 \pm 98$ & & $632 \pm 86$ & \\
\hline 0.1 & $1329 \pm 134$ & & $986 \pm 113$ & \\
\hline 0.2 & $2041 \pm 191$ & & $1782 \pm 242$ & \\
\hline \multicolumn{5}{|c|}{ Glycidyl 3-nitrobenzenesulfonate } \\
\hline 0 & $119 \pm 7$ & $661 \pm 8$ & $119 \pm 7$ & $1050 \pm 23$ \\
\hline 0.1 & $228 \pm 33$ & & $296 \pm 9$ & \\
\hline 0.33 & $373 \pm 17$ & & $566 \pm 40$ & \\
\hline 0.66 & $580 \pm 39$ & & $890 \pm 65$ & \\
\hline 1 & $820 \pm 33$ & & $1239 \pm 58$ & \\
\hline 2 & $1461 \pm 42$ & & $2263 \pm 205$ & \\
\hline \multicolumn{5}{|c|}{ Glycidyl 4-nitrobenzoate } \\
\hline 0 & $132 \pm 14$ & $3883 \pm 99$ & $132 \pm 14$ & $4674 \pm 79$ \\
\hline 0.05 & $394 \pm 18$ & & $398 \pm 20$ & \\
\hline 0.1 & $558 \pm 52$ & & $654 \pm 21$ & \\
\hline 0.2 & $941 \pm 79$ & & $1165 \pm 53$ & \\
\hline 0.4 & $1697 \pm 169$ & & $2013 \pm 268$ & \\
\hline 0.8 & $3276 \pm 372$ & & $3907 \pm 176$ & \\
\hline 1.6 & $2443 \pm 343$ & & $2382 \pm 419$ & \\
\hline
\end{tabular}




\begin{tabular}{|c|c|c|c|c|}
\hline \multirow{2}{*}{$\begin{array}{l}\text { Compounds } \\
\text { Dose } \\
(\mu \mathrm{mol})\end{array}$} & \multicolumn{2}{|l|}{$\mathrm{R}$} & \multicolumn{2}{|l|}{$\mathrm{S}$} \\
\hline & $\begin{array}{l}\text { Revertants } \\
\text { (mean } \pm \text { S.D.) }\end{array}$ & $\mathrm{Rev} / \mu \mathrm{mol}^{\mathrm{a}}$ & $\begin{array}{l}\text { Revertants } \\
\text { (mean } \pm \text { S.D.) }\end{array}$ & $\mathrm{Rev} / \mu \mathrm{mol}$ \\
\hline \multicolumn{5}{|c|}{ Glycidyl 4-nitrophenyl ether } \\
\hline 0 & $124 \pm 11$ & $3099 \pm 90$ & $124 \pm 11$ & $2517 \pm 63$ \\
\hline 0.01 & $198 \pm 27$ & & $172 \pm 23$ & \\
\hline 0.05 & $366 \pm 29$ & & $327 \pm 23$ & \\
\hline 0.1 & $566 \pm 50$ & & $489 \pm 57$ & \\
\hline 0.33 & $1219 \pm 156$ & & $1091 \pm 88$ & \\
\hline 0.66 & $2216 \pm 264$ & & $1799 \pm 151$ & \\
\hline \multicolumn{5}{|c|}{ Glycidyl tosylate } \\
\hline 0 & $144 \pm 27$ & $949 \pm 37$ & $144 \pm 27$ & $1969 \pm 132$ \\
\hline 0.1 & $257 \pm 54$ & & $396 \pm 69$ & \\
\hline 0.33 & $439 \pm 61$ & & $729 \pm 15$ & \\
\hline 0.66 & $799 \pm 190$ & & $1659 \pm 218$ & \\
\hline 1 & $1031 \pm 180$ & & $2408 \pm 467$ & \\
\hline 2 & $2239 \pm 218$ & & $3997 \pm 1041$ & \\
\hline 3 & $2900 \pm 559$ & & $6135 \pm 2169$ & \\
\hline \multicolumn{5}{|l|}{ Styrene oxide } \\
\hline 0 & $129 \pm 28$ & $134 \pm 3$ & $129 \pm 28$ & $77 \pm$ \\
\hline 1 & $216 \pm 19$ & & $180 \pm 11$ & \\
\hline 2 & $359 \pm 35$ & & $244 \pm \quad 13$ & \\
\hline 4 & $584 \pm 17$ & & $377 \pm \quad 33$ & \\
\hline 6 & $972 \pm 79$ & & $592 \pm \quad 86$ & \\
\hline 8 & $1146 \pm 36$ & & $717 \pm 90$ & \\
\hline
\end{tabular}

¿Values are the calculated slopes of the linear portion of the dose-response curve determined by at least two independent experiments.

As reviewed by Hanson (1991), the epoxides in the present study can have a number of different modes of reaction with a nucleophile. While glycidol and benzyloxymethyloxirane undergo ring opening through nucleophilic attack on C-3 of an epoxide of the general structure, $\mathrm{X}-\stackrel{1}{\mathrm{C}}-\stackrel{2}{\mathrm{C}}^{-} \stackrel{3}{\mathrm{C}}^{3}$, glycidyl benzenesulfonates are known to react at $\mathrm{C}-1$ to result in a nucleophilic displacement of the sulfonate groups under basic conditions (Klunder et al., 1989). Epichlorohydrin can react at C-1 (displacement) and undergo ring opening at C-3 (McClure et al., 1979). Styrene oxide, on the other hand, gives ring opening through nucleophilic attack at both its $\alpha$ and $\beta$ carbons (Tamura et al., 1982). Glycidyl 4-nitrobenzoate can hydrolyze first to glycidol and then undergo ring opening upon nucleophilic attack (Ko et al., 1987). Even if only these factors are considered, a complex outcome of genotoxic potencies of the test compounds should be expected.

While there are numerous reports concerning the genotoxicity of the racemic forms of glycidol, epichlorohydrin and styrene oxide, previous studies concerning differences in genotoxicity between the enantiomers in Table 1 are limited. Watabe et al. (1981) did not detect a difference between styrene oxide isomers using Salmonella TA100 in the Ames procedure. However, Pagano et al. (1982) did find the (R)-isomer to be more mutagenic than the (S)-isomer with TA100 and this was confirmed by Seiler (1990). Seiler also presented evidence of qualitative differences in DNA binding between the isomers. Furthermore, Hiratsuka et al. (1989) have shown that (R)styrene oxide conjugates faster with glutathione in rat-liver cytosol than the (S)-isomer while Watabe et al. (1981) have shown the (S)-isomer to be the better substrate for rat-liver microsomal 
hydrolase. Such differences in rates of detoxication could be a factor in explaining differences in genotoxicity of ( $\mathrm{R})$ - and ( $\mathrm{S}$ )-isomers in vivo. $\mathrm{Re}$ cently, von der Hude et al. (1992) completed a study on the in vitro genotoxicity of the enantiomers of glycidol, styrene oxide and glycidyl 4-nitrobenzoate, compounds included in our study, as well as 9 additional pairs of related enantiomeric epoxides. In their investigation of the induction of sister-chromatid exchange (SCE) frequencies with Chinese hamster V79 cells, statistically significant differences were established between isomers for half of the compounds tested.

The goals of the present study are to conduct an investigation of genotoxicity of the new enantiomeric epoxide reagents in comparison to the optical isomers of the established genotoxic compounds, styrene oxide, glycidol and epichlorohydrin, as well as to determine whether there are differences between isomers in genotoxicity both in vitro and in vivo. We have also synthesized the (R)-and (S)-isomers of glycidyl 1-naphthyl ether as well as those of glycidyl 4-nitrophenyl ether so that these compounds, whose genotoxicity has previously been studied in our laboratories as their racemates (Giri et al., 1989; 1990), could be compared as their optical isomers. Similar to benzyloxymethyloxirane, these glycidyl ethers would have nucleophilic attack on C-3 (ring opening) as the predominant mode of reaction. The short-term tests used in these evaluations are the Ames test with Salmonella strain TA100 and chromosomal aberrations (CA) as well as SCE tests in the bone-marrow cells of mice following intraperitoneal (ip) administration of the epoxides. Thus, as suggested by Natarajan and Obe (1986) and Shelby (1988) for screening of compounds for genotoxicity, the detection of point mutations by the widely used Ames bacterial test is supplemented by in vivo evaluations that respond to strand breaks.

\section{Materials and methods}

\section{Test compounds}

The isomers, with the exception of 4 and 7 , listed in Table 1 and 7,12-dimethylbenz[a]anthracene (DMBA) were purchased from Aldrich Chemical Co. (Milwaukee, WI). The optical rota- tions of the epoxides were measured and their purity examined by thin-layer chromatography. The isomers of styrene oxide, glycidol and glycidyl 4-nitrobenzoate required purification by chromatography over silica with hexane-ethyl acetate systems to remove impurities and to meet their original optical specifications. The enantiomers of glycidyl 1-naphthyl ether (4) and glycidyl 4-nitrophenyl ether (7) were synthesized according to the procedure of Klunder et al. (1989) with (R)- or (S)-glycidyl 3-nitrobenzenesulfonate and 1-naphthol or 4-nitrophenol respectively as the reagents. The naphthyl ethers were obtained as oils with the $(\mathrm{R})$-isomer, $[\alpha]_{\mathrm{D}}^{20}-16.4^{\circ}$ (C 2, $\mathrm{CHCl}_{3}$ ) and the (S)-isomer, $[\alpha]_{\mathrm{D}}^{\mathrm{D}}+17.3^{\circ}$ (C 2, $\mathrm{CHCl}_{3}$ ) having enantiomeric excess (\%ee) of 92 and 93 respectively. Recrystallization of the nitrophenyl ethers from methanol gave the (R)-isomer, $[\alpha]_{\mathrm{D}}^{20}-5.1^{\circ}\left(\mathrm{C} \mathrm{0.5,} \mathrm{CHCl}_{3}\right)$ and (S)-isomer, $[\alpha]_{\mathrm{D}}^{20}+4.9^{\circ}\left(\mathrm{C} 0.6, \mathrm{CHCl}_{3}\right)$ each with \%ee $\geqslant 98$. The epoxides were considered suitable for genotoxicity testing only when a sample $(2 \mu \mathrm{l}, 10 \%$ $\mathrm{CH}_{2} \mathrm{Cl}_{2}$ solution) showed a single homogeneous spot after silica gel thin-layer chromatography (ethyl acetate/hexane) under UV observation and after alkylation of 4-(4-nitrobenzyl)pyridine (Hammock et al., 1974).

\section{Mutagenicity assays}

Compounds dissolved in DMSO were tested for dose-mutagenicity relationships using Salmonella typhimurium strain TA100 kindly provided by Dr. Bruce Ames (University of California, Berkeley, CA). As epoxides are direct acting mutagens, the plate incorporation assay without metabolic activation as described by Maron and Ames (1983) was used. Plates were scored with an automatic counter (Autocount, Dynatech Labs, Chantilly, VA) which had been calibrated against manually scored plates. Each dose was run in triplicate and the dose-response relationship confirmed in a second set of tests. Slopes were determined from the combined data.

In vivo tests of bone-marrow cells

Male CD1 mice (10-12 weeks old, $\sim 30 \mathrm{~g}$ ) were purchased from Charles River Breeding Laboratories (Wilmington, MA). They were kept 4 per cage, fed chow (Purina) with water ad 
libitum and housed 4-5 days prior to the start of the experiments. Epoxides $(100 \mathrm{mg} / \mathrm{kg})$ in DMSO $(2 \mathrm{ml} / \mathrm{kg}$ ) which had been administered by ip injection were evaluated for CA and SCE responses in bone-marrow cells. CA and SCE tests were conducted for 4 animals in each procedure for each isomer by our previously described protocols (Giri et al., 1989). For CA, 100 metaphase and for SCE, 30 second-division cells were scored per animal. The dose of $100 \mathrm{mg} / \mathrm{kg}$ was based upon our previous epoxide studies (Giri et al., $1989 ; 1990)$ to avoid acute toxicity and limit cell toxicity, as measured by mitotic or replicative indices, but high enough to obtain a usable range of comparative response. DMBA in DMSO (2 $\mathrm{ml} / \mathrm{kg}$ ) was used as a positive control at 100 $\mathrm{mg} / \mathrm{kg}$ for CA and at $50 \mathrm{mg} / \mathrm{kg}$ for SCE. A response time of $24 \mathrm{~h}$ following the injection of test compounds was used for CA where many second-division cells would be present but where in our experience trichloropropylene oxide, an epoxide with a short half-life, showed no differences for the shorter response times discussed by Preston et al. (1987).

TABLE 3

IN VIVO CHROMOSOMAL ABERRATIONS INDUCED BY EPOXIDE R AND S ISOMERS AT $100 \mathrm{mg} / \mathrm{kg}$

\begin{tabular}{|c|c|c|c|c|c|c|}
\hline \multirow[t]{2}{*}{ Chemical } & & \multirow[t]{2}{*}{ Gaps $^{a}$} & \multicolumn{2}{|c|}{ Aberrations /cell } & \multirow{2}{*}{$\begin{array}{l}\text { Aberrant cells }(\%)^{b} \\
(\text { mean } \pm \text { S.D. })^{c}\end{array}$} & \multirow{2}{*}{$\begin{array}{l}\text { Mitotic indices }(\%) \\
(\text { mean } \pm \text { S.D. })^{c}\end{array}$} \\
\hline & & & $\begin{array}{l}\text { Chromatid } \\
\text { type }\end{array}$ & $\begin{array}{l}\text { Chromosome } \\
\text { type }\end{array}$ & & \\
\hline \multicolumn{7}{|l|}{ Solvent control } \\
\hline DMSO $(2 \mathrm{ml} / \mathrm{kg})$ & & 3.00 & 0.010 & 0.000 & $1.00 \pm 0.82$ & $3.51 \pm 0.30$ \\
\hline \multirow{2}{*}{$\begin{array}{l}\text { Benzyloxymethyl- } \\
\text { oxirane }\end{array}$} & $\mathrm{R}$ & 2.50 & 0.025 & 0.003 & $2.75 \pm 0.50 * *$ & $2.65 \pm 0.15 * *$ \\
\hline & $\mathrm{S}$ & 3.25 & 0.030 & 0.003 & $3.25 \pm 0.96 * *$ & $2.60 \pm 0.35 * *$ \\
\hline \multirow[t]{2}{*}{ Epichlorohydrin } & $\mathrm{R}$ & 2.75 & 0.028 & 0.000 & $2.75 \pm 0.50 * *$ & $2.67 \pm 0.23 * *$ \\
\hline & $\mathrm{S}$ & 2.75 & 0.025 & 0.000 & $2.50 \pm 0.58 *$ & $2.66 \pm 0.35 * *$ \\
\hline \multirow[t]{2}{*}{ Glycidol } & $\mathrm{R}$ & 5.75 & 0.035 & 0.000 & $3.50 \pm 1.00 * *$ & $2.58 \pm 0.42 * *$ \\
\hline & $\mathrm{S}$ & 6.50 & 0.045 & 0.000 & $4.50 \pm 1.29 * *$ & $1.82 \pm 0.14 * *$ \\
\hline \multirow{2}{*}{$\begin{array}{l}\text { Glycidyl 1-naphthyl } \\
\text { ether }\end{array}$} & $\mathrm{R}$ & 3.50 & 0.033 & 0.003 & $3.50 \pm 0.577 * *$ & $2.30 \pm 0.489 * *$ \\
\hline & $\mathrm{S}$ & 4.75 & 0.040 & 0.008 & $4.75 \pm 0.957 * *$ & $2.11 \pm 0.495 * *$ \\
\hline \multirow{2}{*}{$\begin{array}{l}\text { Glycidyl 3-nitro- } \\
\text { benzenesulfonate }\end{array}$} & $\mathrm{R}$ & 3.25 & 0.018 & 0.000 & $1.75 \pm 0.50$ & $2.59 \pm 0.24 * *$ \\
\hline & $\mathrm{S}$ & 1.75 & 0.018 & 0.000 & $1.75 \pm 0.50$ & $2.89 \pm 0.37 *$ \\
\hline \multirow{2}{*}{$\begin{array}{l}\text { Glycidyl 4-nitro- } \\
\text { benzoate }\end{array}$} & $\mathrm{R}$ & 5.75 & 0.030 & 0.008 & $3.75 \pm 0.96 * *$ & $2.90 \pm 0.30 *$ \\
\hline & $\mathrm{S}$ & 4.75 & 0.050 & 0.005 & $5.50 \pm 0.58 * * d$ & $2.73 \pm 0.10 * *$ \\
\hline \multirow{2}{*}{$\begin{array}{l}\text { Glycidyl 4-nitro- } \\
\text { phenyl ether }\end{array}$} & $\mathrm{R}$ & 3.00 & 0.035 & 0.000 & $3.50 \pm 1.000 * *$ & $2.59 \pm 0.458 * *$ \\
\hline & $\mathrm{S}$ & 2.75 & 0.035 & 0.000 & $3.50 \pm 0.577 * *$ & $2.61 \pm 0.459 * *$ \\
\hline \multirow[t]{2}{*}{ Glycidyl tosylate } & $\mathbf{R}$ & 2.25 & 0.013 & 0.000 & $1.25 \pm 0.50$ & $2.74 \pm 0.17 * *$ \\
\hline & $\mathrm{S}$ & 2.75 & 0.013 & 0.000 & $1.25 \pm 0.50$ & $2.78 \pm 0.27 * *$ \\
\hline \multirow[t]{2}{*}{ Styrene oxide } & $\mathrm{R}$ & 3.50 & 0.018 & 0.000 & $1.75 \pm 0.96$ & $2.74 \pm 0.28 * *$ \\
\hline & $\mathrm{S}$ & 4.50 & 0.028 & 0.000 & $2.75 \pm 0.50 * *$ & $2.58 \pm 0.22 * *$ \\
\hline \multicolumn{7}{|l|}{ Positive control } \\
\hline DMBA & & 11.25 & 0.115 & 0.023 & $13.25 \pm 0.96 * *$ & $2.13 \pm 0.12 * *$ \\
\hline
\end{tabular}

a Total chromatid and chromosome gaps at each concentration per 100 cells were recorded but not included as aberrations.

${ }^{b}$ Cells with at least 1 aberration for 4 animals.

c Results were compared to those of the control using Dunnett's test, where statistically significant differences are indicated by $* P<0.05$ and $* * P<0.01$.

${ }^{\mathrm{d}}$ The (R)- and (S)-results were significantly different, where $P<0.05$. 


\section{Results and discussion}

Mutagenicity results are summarized in Table 2 and show that dose-response relationships could be established for each isomer. There are significant differences $(p<0.01)$ between isomers for all the pairs of compounds in Table 2. The (S)isomers for the benzyl ether, nitrobenzenesulfonate, the nitrobenzoate and tosylate show greater mutagenicity than their ( $\mathrm{R}$ )-isomers as measured by revertants per $\mu$ mol. However, the opposite is true for epichlorohydrin, glycidol, glycidyl 1-naphthyl ether, glycidyl 4-nitrophenyl ether and styrene oxide. The benzyloxymethyloxirane isomers had mutagenicity values comparable to the isomers of the established genotoxic compounds epichlorohydrin and styrene oxide but somewhat less than that of glycidol. All the other new reagents exhibited mutagenicities greater than that of these established genotoxic compounds. These in vitro Salmonella results differ with those for the pairs of isomers tested in common with the in vitro Chinese hamster cell study of von der Hude et al. (1992). In their study, no difference was established between the glycidol nor styrene oxide isomers and the (R)glycidyl 4-nitrobenzoate was more genotoxic than its (S)-isomer.

The in vivo $\mathrm{CA}$ results are summarized in Table 3 where the solvent, DMSO, is the negative

TABLE 4

IN VIVO SISTER-CHROMATID EXCHANGES INDUCED BY EPOXIDE R AND S ISOMERS AT $100 \mathrm{mg} / \mathrm{kg}$

\begin{tabular}{|c|c|c|c|c|c|c|c|}
\hline \multirow{2}{*}{$\begin{array}{l}\text { Chemical } \\
\text { Solvent control }\end{array}$} & & \multicolumn{4}{|c|}{ SCE /cell of 4 animals } & \multirow[t]{2}{*}{$\begin{array}{l}\mathrm{SCE} / \text { cell } \\
(\text { mean } \pm \text { S.D.) }\end{array}$} & \multirow[t]{2}{*}{$\begin{array}{l}\text { Replicative indices } \\
\text { (mean } \pm \text { S.D.) }\end{array}$} \\
\hline & & & & & & & \\
\hline DMSO $(2 \mathrm{ml} / \mathrm{kg})$ & & 3.50 & 2.90 & 3.80 & 4.00 & $3.55 \pm 0.48$ & $1.86 \pm 0.06$ \\
\hline \multirow{2}{*}{$\begin{array}{l}\text { Benzyloxymethyl- } \\
\text { oxirane }\end{array}$} & $\mathrm{R}$ & 4.50 & 4.70 & 4.27 & 3.87 & $4.34 \pm 0.36^{*}$ & $1.85 \pm 0.06$ \\
\hline & $\mathrm{S}$ & 4.10 & 4.50 & 5.27 & 4.70 & $4.64 \pm 0.49 * *$ & $1.84 \pm 0.03$ \\
\hline \multirow[t]{2}{*}{ Epichlorohydrin } & $\mathbf{R}$ & 4.87 & 4.40 & 5.23 & 5.43 & $4.98 \pm 0.45 * *$ & $1.82 \pm 0.05$ \\
\hline & $\mathrm{S}$ & 3.57 & 3.27 & 3.83 & 4.30 & $3.74 \pm 0.44^{b}$ & $1.85 \pm 0.07$ \\
\hline \multirow[t]{2}{*}{ Glycidol } & $\mathbf{R}$ & 7.53 & 8.10 & 7.96 & 7.90 & $7.87 \pm 0.24 * *$ & $1.83 \pm 0.06$ \\
\hline & $\mathrm{S}$ & 10.73 & 11.07 & 9.03 & 9.83 & $10.17 \pm 0.92 * b$ & $1.74 \pm 0.05 *$ \\
\hline \multirow{2}{*}{$\begin{array}{l}\text { Glycidyl 1-naphthyl } \\
\text { ether }\end{array}$} & $\mathbf{R}$ & 6.80 & 6.33 & 6.60 & 6.60 & $6.58 \pm 0.19 * *$ & $1.83 \pm 0.04$ \\
\hline & $\mathrm{S}$ & 7.47 & 6.87 & 7.87 & 8.40 & $7.65 \pm 0.65 * c$ & $1.81 \pm 0.03$ \\
\hline \multirow{2}{*}{$\begin{array}{l}\text { Glycidyl 3-nitro- } \\
\text { benzenesulfonate }\end{array}$} & $\mathbf{R}$ & 4.63 & 4.67 & 4.50 & 4.33 & $4.56 \pm 0.11 * *$ & $1.81 \pm 0.05$ \\
\hline & $\mathrm{S}$ & 4.50 & 5.83 & 5.90 & 5.30 & $5.38 \pm 0.65 * \mathrm{c}$ & $1.83 \pm 0.04$ \\
\hline \multirow{2}{*}{$\begin{array}{l}\text { Glycidyl 4-nitro- } \\
\text { benzoate }\end{array}$} & $\mathbf{R}$ & 6.77 & 6.70 & 7.93 & 7.30 & $7.18 \pm 0.57 * *$ & $1.83 \pm 0.05$ \\
\hline & $S$ & 10.00 & 8.30 & 8.67 & 9.73 & $9.18 \pm 0.82 * * b$ & $1.81 \pm 0.04$ \\
\hline \multirow{2}{*}{$\begin{array}{l}\text { Glycidyl 4-nitro- } \\
\text { phenyl ether }\end{array}$} & $\mathrm{R}$ & 6.40 & 5.06 & 4.43 & 4.97 & $5.22 \pm 0.84 * *$ & $1.84 \pm 0.03$ \\
\hline & $\mathrm{S}$ & 5.53 & 5.83 & 5.10 & 6.17 & $5.66 \pm 0.45 * *$ & $1.82 \pm 0.04$ \\
\hline \multirow[t]{2}{*}{ Glycidyl tosylate } & $\mathbf{R}$ & 4.50 & 4.03 & 4.73 & 3.50 & $4.19 \pm 0.55$ & $1.84 \pm 0.04$ \\
\hline & $S$ & 4.93 & 6.67 & 5.60 & 4.73 & $5.48 \pm 0.88 * * c$ & $1.81 \pm 0.06$ \\
\hline \multirow[t]{2}{*}{ Styrene oxide } & $\mathbf{R}$ & 3.60 & 3.63 & 3.30 & 3.90 & $3.61 \pm 0.25$ & $1.85 \pm 0.05$ \\
\hline & $S$ & 5.68 & 4.63 & 4.73 & 5.23 & $5.06 \pm 0.49 * * b$ & $1.81 \pm 0.05$ \\
\hline \multicolumn{8}{|l|}{ Positive control } \\
\hline DMBA $(50 \mathrm{mg} / \mathrm{kg})$ & & 14.2 & 16.4 & 14.8 & 15.2 & $15.15 \pm 0.93 * *$ & $1.79 \pm 0.03$ \\
\hline
\end{tabular}

${ }^{a}$ Mean \pm S.D. for 4 animals (30 cells/animal). Results at each concentration were compared to those of the control using Dunnett's test, where statistically significant differences are indicated by ${ }^{*} P<0.05$ and $* * P<0.01$.

b The (R)- and (S)-results were significantly different, where $P<0.01$.

c Same as above, where $P<0.05$. 


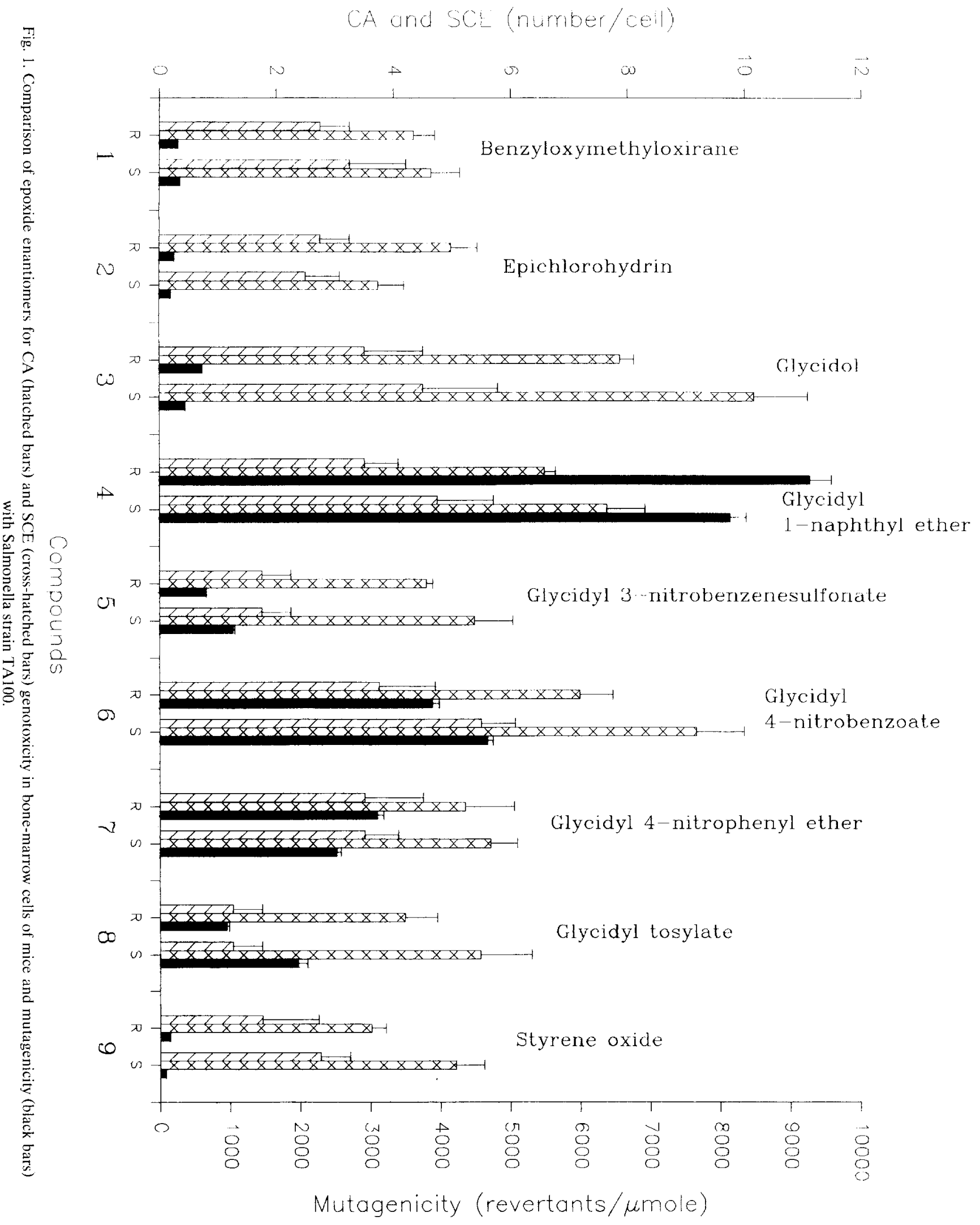


control and DMBA is the positive control. With the exception of the (R)- and (S)-isomers of glycidyl 3-nitrobenzenesulfonate and glycidyl tosylate as well as (R)-styrene oxide, there are statistically significant differences in CA results compared to the negative control. There are also significant decreases in mitotic index for all the compounds tested, indicating toxicity to bonemarrow cells at the $100 \mathrm{mg} / \mathrm{kg}$ dose. The CA values for every epoxide isomer were significantly lower than the strongly genotoxic positive control, DMBA. The CA results for the (S)-glycidyl 4nitrobenzoate and (S)-glycidyl 1-naphthyl ether are comparable. This latter epoxide, previously tested as a racemate, was the most genotoxic compound of a group of four epoxides selected for in vivo evaluation because of their demonstrated high mutagenicity in vitro (Giri et al., $1989 ; 1990)$. While in general it was not possible to determine differences between optical isomers based upon our current results, a significant ( $p<$ $0.05)$ difference was established for the 4-nitrobenzoate isomers, with the (S)-isomer having the greater genotoxicity.

SCE results are summarized in Table 4. As was true for the CA results, all the epoxides were much less genotoxic than the positive control DMBA which was evaluated at half of the dose used for the epoxides. Except for 3 isomers, (S)epichlorohydrin, (R)-glycidyl tosylate and (R)styrene oxide, a difference in genotoxicity was detected for all compounds, at least at the $p<$ 0.05 level, when compared to the negative control. The glycidol and glycidyl 4-nitrobenzoate isomers were distinctly more genotoxic than the other commercially available reagents. This genotoxicity was only approached by the SCE responses for our synthesized (R)- and (S)-isomers of glycidyl 1-naphthyl ether. Only for the (S)glycidol was there a significant $(p<0.05)$ decrease in cell replication kinetics which indicates toxicity to cell division. SCE evaluations proved to be more sensitive in determining differences between the (R)- and (S)-isomers than CA measurements. Except for the benzyloxymethyloxirane and glycidyl 4-nitrophenyl ether isomers, significant differences were established between optical isomers. For all these pairs of isomers, but not including those of epichlorohydrin, the (S)isomer was more genotoxic than the $(\mathrm{R})$-isomer.

The results outlined in Tables 2-4 and the discussion above are summarized in Fig. 1 where the differences among the epoxides and between the enantiomers are presented for the three short-term tests. The CA and SCE evaluations follow a similar pattern of results across compounds and in regard to the relative genotoxicity between ( $\mathrm{S}$ )- and (R)-isomers. However, the greater sensitivity of the SCE test over that of $\mathrm{CA}$ and its increased ability to detect differences between optical isomers is evident in this figure. While there is general agreement between the in vitro Salmonella mutagenicity and the in vivo results as to relative genotoxicity between (R)and (S)-isomers for a given pair of compounds, the in vitro results were not predictive of relative in vivo genotoxicity among different pairs of compounds. For example, the relatively low mutagenicity for the benzyloxymethyloxirane, epichlorohydrin and styrene oxide isomers was not predictive of their moderate genotoxicity in vivo. The most notable difference between in vitro and in vivo results is for the glycidol isomers, where the Salmonella mutagenicity tests were neither predictive of the greater genotoxicity for the (S)-isomer vs. the (R)-isomer in vivo nor of the relatively high genotoxicity in vivo for both isomers in contrast to the other pairs of compounds. The 4-nitrobenzoates were designed to hydrolyze faster than ring opening could occur so that such esters would have functional equivalency to glycidol (Ko et al., 1987). This being the case, then the comparable in vivo genotoxicity for the benzoate and glycidol isomers could be explained on the basis of the esters reaching bonemarrow cells as glycidol. This is in contrast to the comparison of the in vitro mutagenicities of these esters and glycidol isomers where the former isomers have much greater activity than the latter. This would be consistent with much less opportunity for hydrolysis to occur on the Salmonella test plates than in vivo, so that in vitro in contrast to in vivo, non-equivalent mutagens are being compared.

In their applications as organic reagents, the glycidyl sulfonates react under basic conditions 
with nucleophiles to displace the sulfonate groups (Hanson, 1991). It is possible in biological systems that these esters could react with water to yield glycidol. It is apparent, however, that while in vivo conversion to glycidol might contribute to the genotoxicity of these compounds, it can not be as important as is the conversion of the benzoates to glycidol since the levels of genotoxicity for the sulfonates do not match those of glycidol.

It also follows that differences in genotoxicity are due to substituent effects in addition to those contributing to the route of reaction. For example, for the isomers of compounds 1, 3, 4 and 7 in Fig. 1, which can only alkylate bionucleophiles through ring opening at carbon 3 , there are definite differences in the patterns of genotoxicity.

Thus, the literature information concerning differences in the mutagenicity between enantiomeric aliphatic epoxides has been extended to a new group of compounds and has been established in vivo. Differences in the patterns of genotoxicity of the 3 short-term tests employed for our compounds could to a limited degree be related to their differences in chemical reaction pathways.

\section{Acknowledgement}

This investigation was supported by Grant R01 ES03345 from the National Institute of Environmental Health Sciences, DHHS.

\section{References}

Giri, A.K., E.A. Messerly and J.E. Sinsheimer (1989) Sisterchromatid exchange and chromosome aberrations for 4 aliphatic epoxides in mice, Mutation Res., 224, 253-261.

Giri, A.K., E.A. Messerly, P.K. Chakraborty, B.H. Hooberman and J.E. Sinsheimer (1990) DNA strand breaks in liver for four aliphatic epoxides in mice, Mutation Res., $242,187-194$.

Hammock, L.G, B.D. Hammock and J.E. Casida (1974) Detection and analysis of epoxides with 4-( $p$-nitrobenzyl)pyridine, Bull. Environ. Contam. Toxicol., 12, 759-764.

Hanson, R.M. (1991) The synthetic methodology of non- racemic glycidol and related 2,3-epoxy alcohols, Chem. Rev., 91, 436-475.

Hiratsuka, A., A. Yokoi, H.Iwata, T. Watabe, K. Satoh, I. Hatyama and K. Sato (1989) Glutathione conjugation of styrene 7,8-oxide enantiomers by major glutathione transferase isoenzymes isolated from rat livers, Biochem. Pharmacol., 38, 4405-4413.

Klunder, J.M., T. Onami and K.B. Sharpless (1989) Arenesulfonate derivatives of homochiral glycidol: Versatile chiral building blocks for organic synthesis, J. Org. Chem., 54, 1295-1304.

Ko, S.Y., H. Masamune and K.B. Sharpless (1987) p-Nitrobenzoate esters of epoxy alcohols: Convenient synthons for water-soluble epoxy alcolols, J. Org. Chem., 52, 667-671.

Maron, D.M., and B.N. Ames (1983) Revised methods for the Salmonella mutagenicity test, Mutation Res., 113, 173-215.

McClure, D.E., B.H. Arison and J.J. Baldwin (1979) Mode of nucleophilic addition to epichlorohydrin and related species: chiral aryloxymethyloxiranes, J. Amer. Chem. Soc., 101, 3666-3668.

Natarajan, A.T, and G. Obe (1986) How do in vivo mammalian assays compare to in vitro assays in their ability to detect mutations?, Mutation Res., 167, 189-201.

Pagano, D.A., B. Yagen, O. Hernandez, J.R. Bend and E. Zeiger (1982) Mutagenicity of (R) and (S) styrene 7,8-oxide and the intermediary mercapturic acid metabolites formed from styrene 7,8-oxide, Environ. Mutagen., 4, 575-584.

Prelog, V., and G. Helmchen (1982) Basic principles of the CIP-system and proposals for a revision, Angew. Chem. Int. Ed. Engl., 21, 567-583.

Preston, R.J., B. Dean, S. Galloway, H. Holden, A.F. McFee and M. Shelby (1987) Mammalian in vivo cytogenetic assays. Analysis of chromosomal aberrations in bone marrow cells, Mutation Res., 189, 157-165.

Seiler, J.P. (1990) Chirality-dependent DNA reactivity as the possible cause of the differential mutagenicity of the two components in an enantiomeric pair of epoxides, Mutation Res., 245, 165-169.

Shelby, M.D. (1988) The genetic toxicity of human carcinogens and its implications, Mutation Res., 204, 3-15.

Tamura, N., K. Takahashi, N. Shirai and Y. Kawzoe (1982) Studies on chemical carcinogens. XXI. Quantitative structure-mutagenicity relationship among substituted styrene oxides, Chem. Pharm. Bull., 30, 1393-1400.

von der Hude, W., S. Carstensen, R. Gurtler and G. Obe (1992) Structure-activity relationships of epoxides: induction of sister-chromatid exchanges in V79 cells by enantiomeric epoxides, Mutation Res., 278, 289-297.

Watabe, T., N. Ozawa and K. Yoshikawa (1981) Stereochemistry in the oxidative metabolism of styrene by hepatic microsomes, Biochem. Pharmacol., 30, 1695-1698. 